\title{
PREPARATION OF FERROCENE CORE DENDRIMERS AND IMMOBILIZATION OF AChE FOR DETECTION OF DICLOFOP-METHYL HERBICIDE
}

\author{
Nurdan Kurnaz Yetim ${ }^{1, *}$, Nurşen Sari ${ }^{2}$ \\ ${ }^{1}$ Department of Chemistry, Faculty of Arts and Science, Kurklareli University, Kırklareli, Turkey \\ ${ }^{2}$ Department of Chemistry, Faculty of Science, Gazi University, 06500 Ankara, Turkey \\ nurdankurnazyetim@klu.edu.tr
}

\begin{abstract}
The aim of this work was to investigate diclofop-methyl detection (found in a variety of herbicides) using novel dendrimers that have ferrocene cores, as well as their $\mathrm{Pt}(\mathrm{II})$ and $\mathrm{Pt}(\mathrm{IV})$ complexes. Novel dendrimer structures were synthesized and characterized by molar conductivity, magnetic susceptibility, FTIR, UV-Vis, ${ }^{1} \mathrm{H}-\mathrm{NMR}$ and LC-MS methods. Then, the AChE (acetylcholine esterase) enzyme was immobilized on the novel dendrimers, and the optimal parameters $(\mathrm{pH}$, temperature, repeated use, storage stability, substrate concentration) were determined for immobilized AChE. Lastly, changes in absorbance intensity were measured, and calibration graphs were plotted that reflect the inhibition reaction of immobilized AChE with diclofop-methyl. The inhibition interaction of the enzyme immobilized to the $\mathrm{Pt}(\mathrm{II})$ ion containing dendrimers was higher than that of the $\mathrm{Pt}(\mathrm{IV})$ ion containing dendrimers.
\end{abstract}

Keywords: ferrocene; dendrimers; diclofop-methyl; acetylcholinesterase; immobilization

\section{ПОДГОТОВКА НА ДЕНДРИМЕРИ СО ЈАДРО ОД ФЕРОЦЕН И ИМОБИЛИЗАЦИЈА НА АСhЕ ЗА ДЕТЕКЦИЈА НА ХЕРБИЦИДОТ ДИКЛОФОП-МЕТИЛ}

Целта на ова истражување беше да се испита детекцијата на диклофоп-метил (што се наоѓa во повеќе хербициди) со употреба на нови дендримери што имаат јадро од фероцен, како и нивните комплекси што содржат јони на Pt(II) и Pt(IV). Беше извршена синтеза на нови дендримерски структури што беа карактеризирани преку нивната моларна спроводливост, магнетната чувствителност, FTIR, UV-Vis, ${ }^{1} \mathrm{H}-\mathrm{NMR}$ и LC-MS методи. Потоа ензимот ацетилхолин естераза (AChE) беше имобилизиран на новите дендримери и беа определени оптималните параметри (pH, температура, повторувана употреба, стабилност при складирање, концентрација на супстратот) за имобилизираниот AChE. Најпосле, беа измерени промените во интензитетот на апсорпција и беа подготвени калибрациски криви што ја одразуваат реакцијата на инхибиција на имобилизираниот $\mathrm{AChE}$ со диклофоп-метил. Реакцијата на инхибиција на ензимот имобилизиран на дендримерите што содржат јони на $\mathrm{Pt}(\mathrm{II})$ беше повисока во сборедба со дендримерите што содржат јони на Pt(IV).

Клучни зборови: фероцен; дендримери; диклофоп-метил; ацетилхолинестераза имобилизација

\section{INTRODUCTION}

Dendrimers are monodisperse macromolecules in a spherical branched structure. Their formation starts from a nuclear atom and is shaped through the repeated chemical reactions. Dendrimers can be expanded to the desired size by adding successive layers [1-3]. The gaps in the dendrimers enable the transference of the molecules and/or nanoparticles contained in them into any environment. Non-covalent interaction between the guest-host is effective in the occurrence of such a transfer [4]. Also, thanks to their donoracceptor groups and large surface areas, the enzyme allows them to be used as a support material in immobilization $[5,6]$. One of the most important 
events in the field of dendrimer chemistry is the incorporation of transition metals into the dendritic structures as a functional material with electrochemical and catalytic properties. Gaps exist between dendrimer arms and surface groups, which indicates that dendrimers are suitable candidates for catalysis applications. In particular, placing the controlled number of organometallic redox active groups at the centre of the branched structures helps the functionalization of the dendrimers $[7,8]$. Among metallodendrimers, those containing ferrocene show high potential in electrochemistry, particularly in relation to the development of nonreactive biosensors [9]. Lee and colleagues prepared a biosensor that contains an $\mathrm{AChE} / \mathrm{ChOx}$ binary enzyme system for the electrochemical determination of the diazone assay, used for pest removal. Ferrocene was used as a mediator, thus indicating that ferrocene was involved in a bioelectrocatalysis [10].

Today, pesticide-related poisonings are frequently encountered in humans and animals [11, 12]. Pesticides, especially agrochemicals, are used in farming to kill weeds and insects. Herbicides are used to control unwanted plants [13]. Herbicides disrupt the hormonal balance that regulates plant metabolism, such as cell division, cell elongation, protein synthesis and respiration [14]. Therefore, determination of these substances is vital $[15,16]$. Gas chromatography (GC) and high-performance liquid chromatography (HPLC) are common methods used in the detection of diclofop-methyl. Liu and colleagues have previously used gas chromatography to detect the residual diclofop-methyl in both soil and plant samples. The amount of residual diclofop-methyl was found to be between 0.01 and $0.05 \mathrm{mg} / \mathrm{kg}$ for the investigated samples [17]. Özhan and colleagues developed a simple and precise method to simultaneously analyze the herbicides (chlorsulfuron, diuron, bentazone, linuron, chlorpropham, fenoxoprop-ethyl, MCPA, diclofopmethyl, fluazifop-butyl and trifluraline) in water samples. The group used the high-performance liquid chromatography with a diode-array detector (HPLC-DAD) method and determined the amount of pesticides to be between 0.012 and $0.035 \mu \mathrm{g}^{-1}$ for the investigated samples [18]. Baali and colleagues produced impedimetric organic biosensors where the Candida rugosa lipase enzyme was added to the bovine serum albumin (BSA) and glutaraldehyde organic matrix to detect the organochloride pesticides in aqueous solutions [19]. The AChE enzyme may be used to determine these substances, due to AChE enzyme inhibition in pesticide media. The AChE enzyme reacts with acetylthiocholine iodide. A yellow-colored solution (5-mercapto-2-nitrobenzoic acid) is formed in the presence of the colorant 5,5'-dithiobis(2-nitrobenzoic acid) (DTNB), which was produced when DTNB was added to the reaction medium. If the AChE enzyme is inhibited, no yellow-colored product occurs. By immobilizing the enzyme, the aforementioned reactions may be used several times.

In this study, our motivation is to detect diclofop-methyl, which is widely used in pesticide control, using an immobilized AChE enzyme. For this purpose, metal-containing dendrimers were synthesized (Fig. 1). Enzyme immobilization studies of the first- and second-generation dendrimers have previously been reported [20]. In our previous work, the AChE enzyme was immobilized to the support material. The applicability of the immobilized enzyme in pesticide determination was investigated. The inhibition interaction of the enzyme immobilized to the dendrimers containing the $\mathrm{Pt}(\mathrm{II})$ ion with herbicide was found to be higher than the inhibition interaction with immobilized dendrimers containing the $\mathrm{Pt}(\mathrm{IV})$ ion. The reason for this is that $\mathrm{Pt}(\mathrm{II})$ dendrimers have a planar structure and are effective in maintaining the threedimensional structure of the enzyme as a result of the interaction with the enzyme, thus allowing for competition of the substrate and pesticide.

\section{EXPERIMENTAL SECTION}

\subsection{Materials and methods}

1,1'-Ferrocenedicarboxaldehyde; melamine; glutaraldehyde; 2-amino-5-nitrophenol; platinum(II) chloride; platinum(IV) chloride; toluene; acetone; DMSO; acetylcholinesterase (type C3389, from electric eel, 518 units per $\mathrm{mg}, 10 \mathrm{KU}$ ); 5,5'-dithiobis(2nitrobenzoic acid); acetylthiocholine iodide and diclofop-methyl (methyl 2-[4-(2,4-dichlorophenoxy) phenoxy]propanoate) were purchased from Sigma (St. Louis, MO). All other chemicals used in this work were provided by Sigma-Aldrich and were used without further purification.

Elemental analysis $(\mathrm{C}, \mathrm{H}, \mathrm{N})$ was carried out using a LECO-932 CHNS analyzer, and the Fe concentrations were determined on an Atomic Absorption Spectrophotometer Perkin-Elmer 2380. Infrared spectra were recorded on a Bruker Vertex80 FTIR-ATR spectrometer between 4000 and 450 $\mathrm{cm}^{-1}$. ${ }^{1} \mathrm{H}$ Nuclear Magnetic Resonance (NMR) spectra was recorded between 0 and $13 \mathrm{ppm}$ on Jeol JNM-LA 500 FTNMR. ${ }^{1} \mathrm{H}$ NMR spectra were recorded with a Bruker DPX-300 MHz and 100 $\mathrm{MHz}$ using tetramethylsilane (TMS) as an internal standard and DMSO- $d_{6}$ as the solvent. Electronic spectra were recorded on a UV-1800 ENG240V 
spectrophotometer in dimethylformamide (DMF). Melting points were determined with a BarnsteadElectrothermal-9200 melting point apparatus. The molar conductivities were measured with an inoLab Cond 730 conductivity meter $\left(5 \cdot 10^{-4} \mathrm{moll}^{-1}\right.$ in DMF solution). Magnetic measurements were performed with a Sherwood Scientific Magnetic Susceptibility Balance (Model No: MK 1) at $26 \pm$ $0.1{ }^{\circ} \mathrm{C}$ with $\mathrm{Hg}\left[\mathrm{Co}(\mathrm{NCS})_{4}\right]$ as a calibration.

\subsection{Synthesis of extended second-generation} dendrimer: $\left[2 \mathrm{G}-\mathrm{NO}_{2}-\mathrm{Pt}(\mathrm{II})\right]$ and $\left[2 \mathrm{G}-\mathrm{NO}_{2}-\mathrm{Pt}(\mathrm{IV})\right]$

First-generation $(1 \mathrm{G})$ and second-generation (2G) dendrimers were previously synthesized by our group [20, 21]. In this work, $1 \mathrm{G}$ and $2 \mathrm{G}$ dendrimers were reacted with 2-amino-5-nitrophenol and
$\mathrm{Pt}(\mathrm{II}) / \mathrm{Pt}(\mathrm{IV})$ metal salts, and extended second-

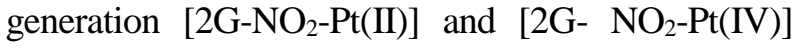
dendrimers were obtained (see Fig. 1). A solution of the $2 \mathrm{G}$ is dissolved in $20 \mathrm{ml} \mathrm{DMF} / \mathrm{CH}_{3} \mathrm{OH}(1: 5 \mathrm{v} / \mathrm{v})$. The solution was stirred magnetically at room temperature. $8 \cdot 10^{-3} \mathrm{~mol}(1.233 \mathrm{~g})$ of 2-amino-5nitrophenol was dissolved in $\mathrm{CH}_{3} \mathrm{OH}(10 \mathrm{ml})$, added dropwise to the solution of the $2 \mathrm{G}$, and the resulting solution was stirred and heated again at room temperature for an hour. An $8 \cdot 10^{-3}$ mol quantity of metal(II) chloride $\left(\mathrm{PtCl}_{2}: 2.128 \mathrm{~g}, \mathrm{PtCl}_{4}: 2.695 \mathrm{~g}\right)$ dissolved in DMF $(10 \mathrm{ml})$ was added drop by drop to the mixture solution. The mixture was magnetically stirred for 1 day and heated to $85^{\circ} \mathrm{C}$. The complexes were precipitated from the solution using toluene and were filtered and washed with 1:1 methanol/toluene. They were then dried in a vacuum oven.

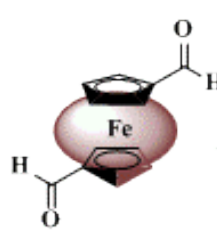<smiles>Nc1nc(N)nc(N)n1</smiles>

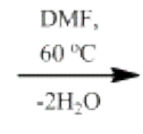

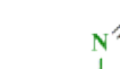<smiles>[CH]=C</smiles>
$\mathrm{CH}$

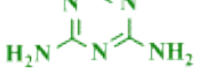
1G

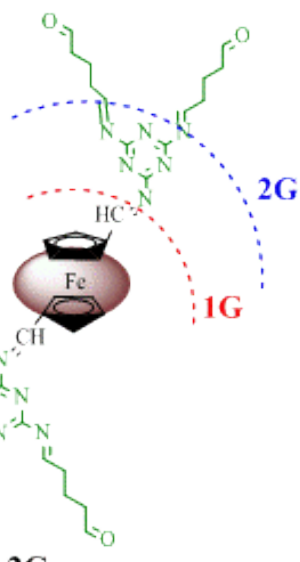

2G

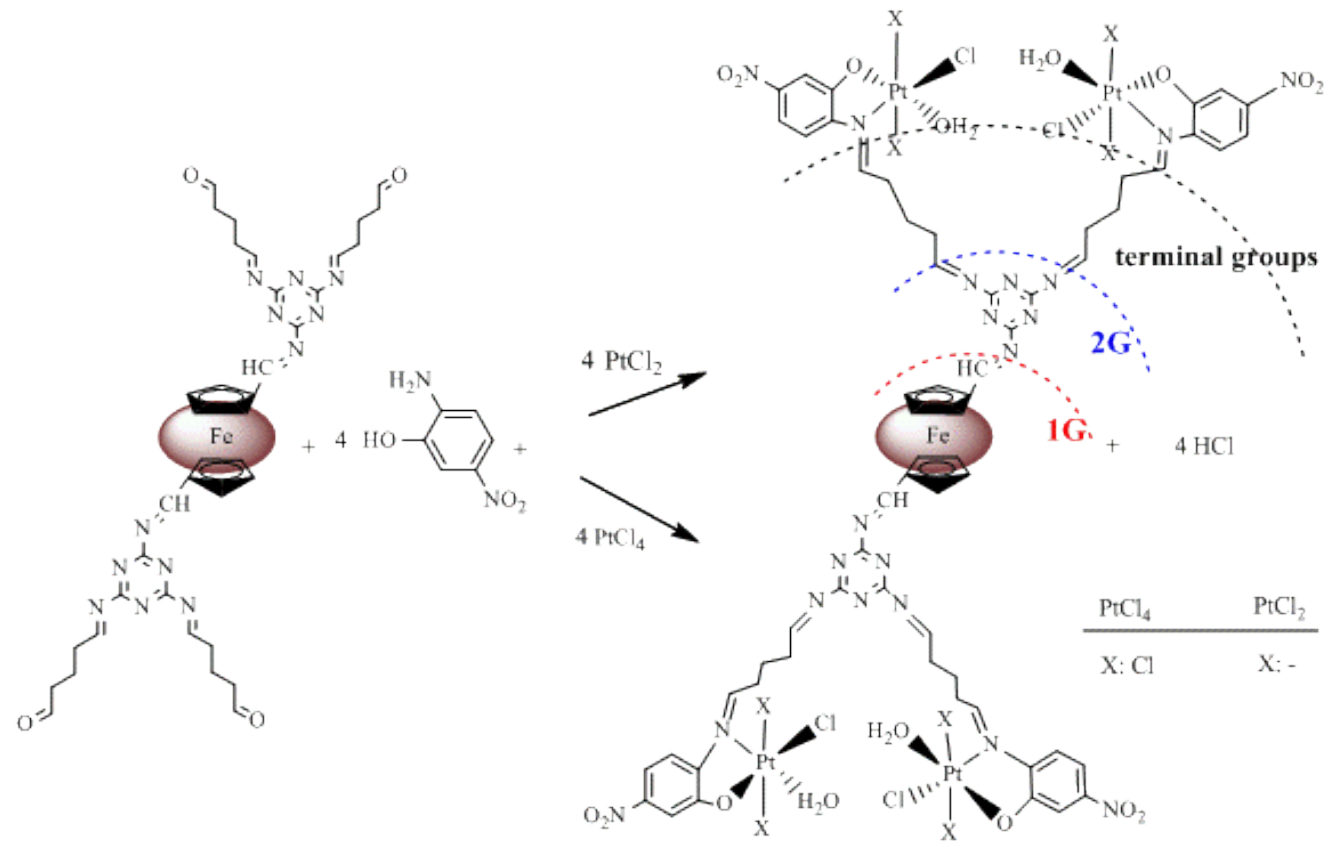

Fig. 1. Synthesis schematics of the first, second and extended second-generation dendrimers 


\subsection{Enzyme immobilization and optimization studies}

\subsubsection{Immobilization of AChE on $2 G$, $\left[2 \mathrm{G}-\mathrm{NO}_{2}-\mathrm{Pt}(\mathrm{II})\right]$ and $\left[2 \mathrm{G}-\mathrm{NO}_{2}-\mathrm{Pt}(\mathrm{IV})\right]$}

Firstly, the AChE enzyme was dissolved in deionized water $\left(50 \mathrm{ml}, 3.6 \cdot 10^{-4} \mathrm{~g} \mathrm{l}^{-1}\right)$, and then, 2 $\mathrm{ml}$ of AChE enzyme solution was added into $0.5 \mathrm{~g}$ of $2 \mathrm{G}, 2 \mathrm{G}-\mathrm{NO}_{2}-\mathrm{Pt}(\mathrm{II})$ and $2 \mathrm{G}-\mathrm{NO}_{2}-\mathrm{Pt}(\mathrm{IV})$ den- drimers. The mixture was stirred for 1 day on a magnetic stirrer at room temperature to allow immobilization. At the end of the reaction, the immobilized dendrimers were removed from the solution medium by filtration and stored at $+4{ }^{\circ} \mathrm{C}$ (Fig. 2). The saturation ratio was determined to be $98.60 \%$, $85.75 \%$ and $80.45 \%$ for $2 \mathrm{G},\left[2 \mathrm{G}-\mathrm{NO}_{2}-\mathrm{Pt}(\mathrm{II})\right]$ and $\left[2 \mathrm{G}-\mathrm{NO}_{2}-\mathrm{Pt}(\mathrm{IV})\right]$, respectively, from an absorbance value in $412 \mathrm{~nm}$.

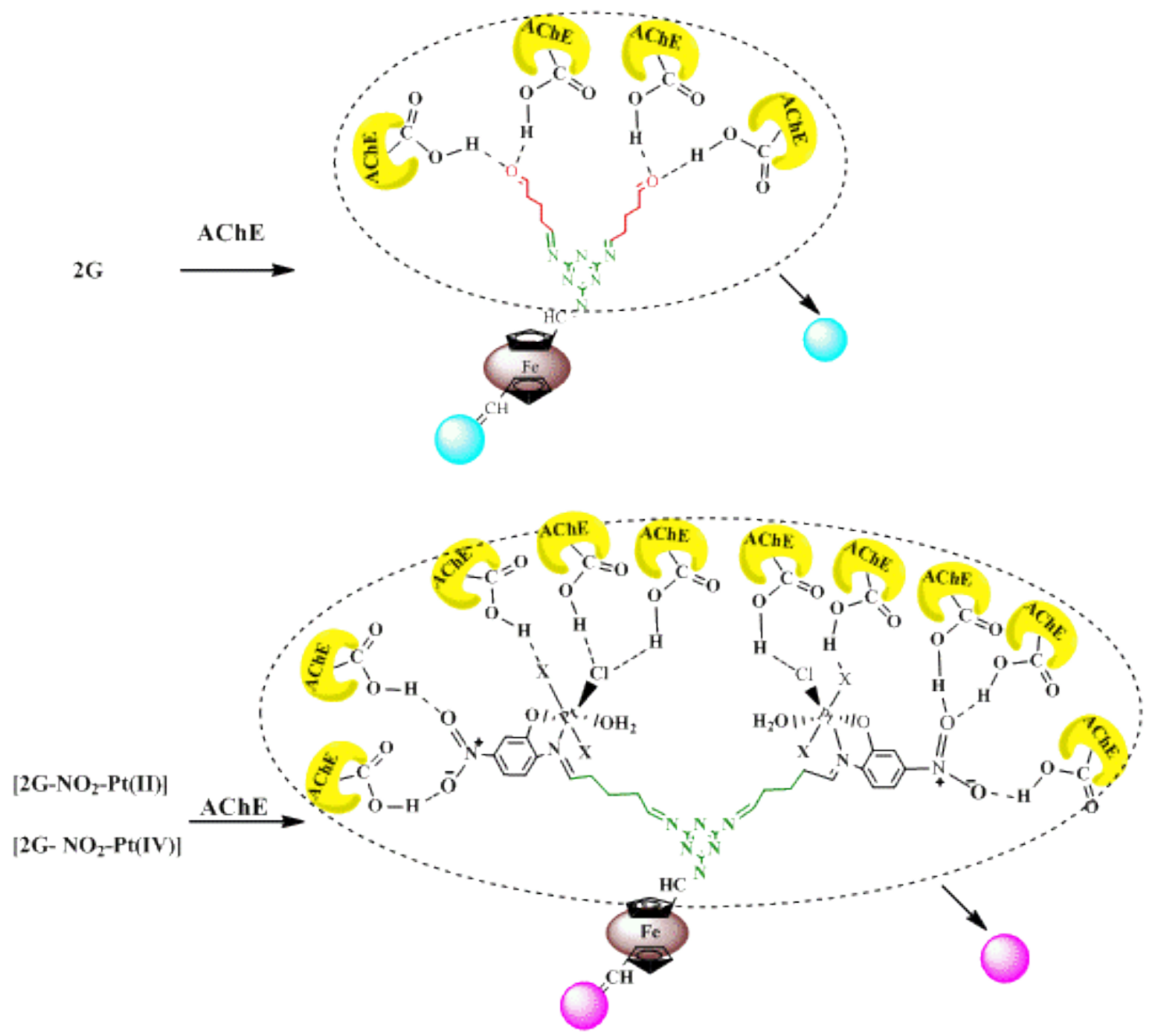

Fig. 2. Schematic representation of enzyme immobilization to synthesized dendrimers

\subsubsection{Assay for enzyme activity measurement}

Ellman's spectrophotometric method was used to determine the activity of the enzyme acetylcholinesterase [22]. The AChE enzyme gives a reaction with the substrate acetylthiocholine iodide. The thiocholine iodide reacts with 5,5'dithiobis(2-nitrobenzoic acid) (DTNB) to form a yellow compound (5-mercapto-2-nitrobenzoic acid). The maximum absorbance of this compound is
$412 \mathrm{~nm}$. The enzyme activity was determined by monitoring the absorbance change in this wavelength.

\subsubsection{Effect of $p H$ and temperature on activity of free and immobilized AChE}

Seven different tubes were prepared, and 2.0 $\mathrm{mg}$ of an AChE enzyme immobilized dendrimer was placed into each tube. The following recipe 
was used for the free and immobilized AChE assay: $4 \mathrm{ml}$ of the studied buffer $(\mathrm{pH} \mathrm{3-9)}+20 \mu \mathrm{l}$ of acetylthiocholine $(0.075 \mathrm{M})+50 \mu \mathrm{l}$ of DTNB $(0.01 \mathrm{M})$ were mixed and added to each tube. Absorbance change was monitored using a ultraviolet-visible (UV-Vis) spectrophotometer.

To examine the effect of temperature on immobilized enzyme activity, immobilized dendrimers were put on buffer solutions at optimum $\mathrm{pH}$. Incubation was performed at temperatures ranging from $20-90{ }^{\circ} \mathrm{C}$. Subsequently, the enzyme activity was measured.

\subsubsection{Effect of substrate}

To investigate the effect of the substrate concentration on the activity of the immobilized enzyme, immobilized dendrimers were added to the substrate solution (acetylthiocholine iodide) at different concentrations $(10-50 \mu \mathrm{l} / 0.075 \mathrm{M})$. The enzyme activity was measured by providing the incubation reaction. A Lineweaver-Burk calibration graph was drawn, and $K_{\mathrm{m}}$ and $V_{\max }$ values were determined.

\subsubsection{Storage stability and reusability of immobilized enzyme}

Storage stability experiments were carried out to determine the stabilities of the immobilized enzymes after storage in dry conditions at $+4{ }^{\circ} \mathrm{C}$ over 8 months. The enzyme activity was measured every 30 days. The observed results were compared to the initial activities. To evaluate the reusability, the acetylcholinesterase immobilized dendrimers were also washed with a buffer solution after any run and were reintroduced into a fresh solution. Reaction cycles were performed under the conditions ( $\mathrm{pH}=8.0$, at room temperature) described above. The enzyme activity was measured.

\subsubsection{Qualitative determination of pesticides by immobilized AChE enzyme}

Pesticides inhibit the enzyme by covalent bonding to the hydroxyl group of the serine amino acid in the active site of the enzyme acetylcholinesterase. In Figure 3, the mechanism of inhibition that is possible between the enzyme and diclofopmethyl is given.
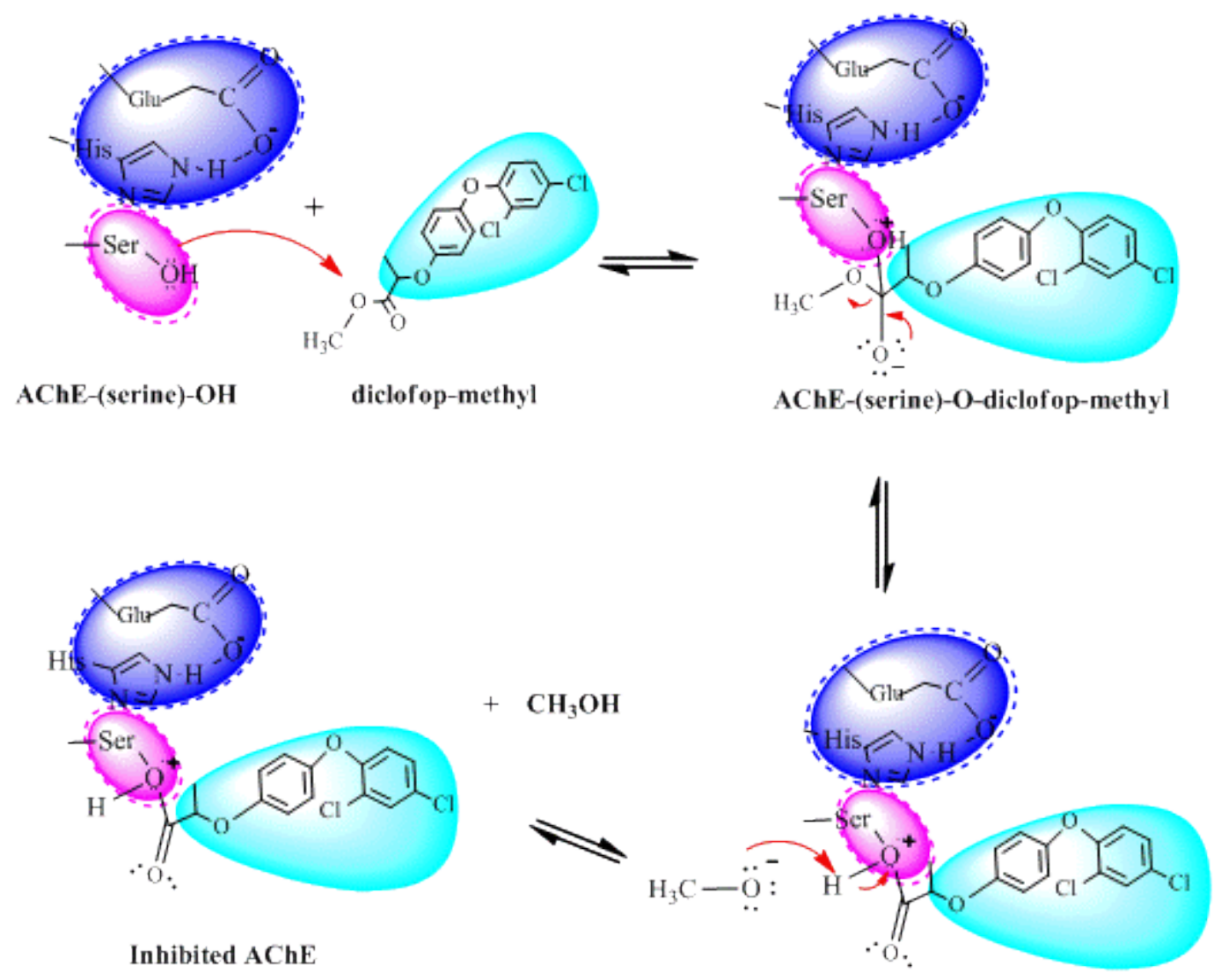

Fig. 3. Mechanism of inhibition that is possible between the enzyme and diclofop-methyl 
For the herbicide detection, firstly, a $5.86 \cdot 10^{-8} \mathrm{M}$ solution of diclofop-methyl was prepared in a water/acetonitrile mixture $(19: 1 \mathrm{v} / \mathrm{v})$. Then, varying volumes of diclofop-methyl solution in the range of 10 to $50 \mu 1$ were added to the immobilized dendrimers (2G-AChE, 2G-NO ${ }_{2}-\mathrm{Pt}(\mathrm{II})$ $\mathrm{AChE}$ and $\left.2 \mathrm{G}-\mathrm{NO}_{2}-\mathrm{Pt}(\mathrm{IV})-\mathrm{AChE}\right)$. Absorbance values of $412 \mathrm{~nm}$ wavelength were measured by the spectrophotometer. Then, $\Delta_{\text {abs }}$ was calculated from the formula below:

$$
\Delta_{\text {abs }}=A_{\text {herbicide }}-A_{\text {dendrimer+herbicide }}
$$

\section{RESULTS AND DISCUSSION}

Novel dendrimers with ferrocene cores and their $\mathrm{Pt}(\mathrm{II})$ and $\mathrm{Pt}(\mathrm{IV})$ complexes were synthesized and characterized by different physicochemical methods, including molar conductivity measurements and spectroscopic (IR, UV-Vis, LC-MS and ${ }^{1} \mathrm{H}$ NMR) techniques. The products obtained ranged from black to brown and are air-stable in the solid state. The dendrimers are only soluble in $\mathrm{C}_{2} \mathrm{H}_{5} \mathrm{OH}$, DMF and DMSO and are insoluble in an apolar solvent such as $\mathrm{CCl}_{4}$ and benzene. The molar conductance values of dendrimers containing $\mathrm{Pt}(\mathrm{II})$ and $\mathrm{Pt}(\mathrm{IV})$ are found to be $28 \Omega^{-1} \mathrm{~cm}^{2} \mathrm{~mol}^{-1}$ and $68.4 \Omega^{-1} \mathrm{~cm}^{2} \mathrm{~mol}^{-1}$ in $5 \cdot 10^{-4} \mathrm{M}$ DMF solutions, respectively (Table 1). According to these results, dendrimers are nonelectrolytes [23]. The magnetic moment of dendrimers containing Pt(II) and $\mathrm{Pt}(\mathrm{IV})$ indicates that these complexes are diamagnetic. Dendrimers containing metal have a square planar and octahedral geometry for dendrimers including Pt(II) and dendrimers including $\mathrm{Pt}(\mathrm{IV})$, respectively.

Table 1

Colors, partial elemental analyses and molar conductivity measurements of the synthesized dendrimers

\begin{tabular}{|c|c|c|c|c|c|c|c|}
\hline \multirow{2}{*}{ Compound } & \multirow{2}{*}{ Color } & \multirow{2}{*}{$\lambda^{\circ} \mathrm{M}^{*}$} & \multicolumn{5}{|c|}{ Found (Calc.) \% } \\
\hline & & & $\mathrm{C}$ & $\mathrm{H}$ & $\mathrm{N}$ & $\mathrm{Pt}$ & $\mathrm{Fe}$ \\
\hline $\begin{array}{l}2 \mathrm{G}-\mathrm{NO}_{2}-\mathrm{Pt}(\mathrm{II}) \\
\mathrm{C}_{62} \mathrm{H}_{62} \mathrm{Cl}_{4} \mathrm{FeN}_{20} \mathrm{O}_{16} \mathrm{Pt}_{4} \\
(2321.2)\end{array}$ & Brown & 28 & $\begin{array}{l}32.79 \\
(32.08)\end{array}$ & $\begin{array}{c}3.06 \\
(2.69)\end{array}$ & $\begin{array}{c}12.35 \\
(12.07)\end{array}$ & $\begin{array}{c}34.10 \\
(33.62)\end{array}$ & $\begin{array}{c}1.99 \\
(2.41)\end{array}$ \\
\hline $\begin{array}{l}2 \mathrm{G}_{-} \mathrm{NO}_{2}-\mathrm{Pt}(\mathrm{IV}) \\
\mathrm{C}_{62} \mathrm{H}_{62} \mathrm{Cl}_{12} \mathrm{FeN}_{20} \mathrm{O}_{16} \mathrm{Pt}_{4} \\
(2604.9)\end{array}$ & Dark brown & 68.4 & $\begin{array}{c}29.94 \\
(28.59)\end{array}$ & $\begin{array}{c}2.61 \\
(2.40)\end{array}$ & $\begin{array}{c}11.11 \\
(10.75)\end{array}$ & $\begin{array}{l}30.40 \\
(29.96)\end{array}$ & $\begin{array}{c}2.01 \\
(2.14)\end{array}$ \\
\hline
\end{tabular}

$* \Omega^{-1} \mathrm{~cm}^{2} \mathrm{~mol}^{-1}$

\subsection{IR, UV-visible, LC-MS and NMR spectra of second and expanded second-generation dendrimers including azomethine}

Table 2 summarizes the main infrared (IR) spectra results of the extended second-generation dendrimers. For the IR bands in extended secondgeneration dendrimers including azomethine $[2 \mathrm{G}-$ $\left.\mathrm{NO}_{2}-\mathrm{Pt}(\mathrm{II})\right]$ and $\left[2 \mathrm{G}-\mathrm{NO}_{2}-\mathrm{Pt}(\mathrm{IV})\right]$, the azomethine bands in the IR spectra of the extended secondgeneration dendrimer appear in the range of 1600 $1650 \mathrm{~cm}^{-1}$. The bands in the 2915-2914 $\mathrm{cm}^{-1}$, $3055-3053 \mathrm{~cm}^{-1}$ and $1245-1242 \mathrm{~cm}^{-1}, 1458-1456$ $\mathrm{cm}^{-1}$ regions are ascribed to $\mathrm{vCH}_{\text {aliphatic }}, v \mathrm{CH}_{\text {aromatic }}$ vibrations and ferrocene vibrations, respectively [24-26]. The IR spectra of all extended secondgeneration dendrimers exhibit characteristic bands of coordination water at ca. $3300 \mathrm{~cm}^{-1}$ and 1600 $\mathrm{cm}^{-1}$ assigned to $v_{\mathrm{H} 2 \mathrm{O}}$ and $\delta_{\mathrm{H} 2 \mathrm{O}}$ vibrations, respectively $[26,27]$. These observations clearly suggest that the water molecules are coordinated to the metal ion (Fig. 1). The appearance of bands in the 486-483 and 563-761 $\mathrm{cm}^{-1}$ regions are due to $v(\mathrm{Pt}-\mathrm{N})$ and $v(\mathrm{Pt}-\mathrm{O})$, respectively [24]. On the basis of the IR spectral results, it may be deduced that the anion of the Schiff base is coordinated to the metal ion as a bidentate ligand (Fig. 1).

Electronic absorption spectra of the $[2 \mathrm{G}$ $\left.\mathrm{NO}_{2}-\mathrm{Pt}(\mathrm{II})\right]$ and [2G-NO$\left.{ }_{2}-\mathrm{Pt}(\mathrm{IV})\right]$ complexes were recorded in spectroscopic grade DMF, and their tentative assignments are given in Table 3. The electronic spectra of dendrimers in DMF show that bands ca. $300 \mathrm{~nm}$ are attributed to the azomethine $\mathrm{n} \rightarrow \pi^{*}(-\mathrm{C}=\mathrm{N})$ transition. The bands at higher energies (201-207, 296-300, 253-257 nm) are associated with the benzene $\sigma \rightarrow \sigma^{*}, \mathrm{n} \rightarrow \pi^{*}{ }_{(\mathrm{C}=\mathrm{N})}$ and $\pi \rightarrow \pi^{*}$ transition [25]. The d-d bands from the spectra of the Fc molecule having low intensities appeared at 389-392 nm [25]. Dendrimers including Pt(IV) observed d-d bands ca, $540 \mathrm{~nm}$ [27]. 
Table 2

Infrared spectroscopic assignments $\left(\mathrm{cm}^{-1}\right)$ for the synthesized dendrimers

\begin{tabular}{lcccccccc}
\hline \hline Compound & $v(\mathrm{C}=\mathrm{N})$ & $v\left(\mathrm{NH}_{2}\right)$ & $v \mathrm{CH}$ (ald.) & $v(\mathrm{C}-\mathrm{H})_{\text {aliph. }}$ & $v(\mathrm{C}-\mathrm{H})_{\text {arom. }}$ & $v \mathrm{M}-\mathrm{N}$ & $v \mathrm{M}-\mathrm{O}$ \\
\hline $2 \mathrm{G}-\mathrm{NO}_{2}-\mathrm{Pt}(\mathrm{II})$ & 1638 & 1630 & - & - & 2915 & 3053 & 483 & 561 \\
& 1622 & & & - & & & & \\
$2 \mathrm{G}-\mathrm{NO}_{2}-\mathrm{Pt}(\mathrm{IV})$ & 1640 & 1625 & - & - & 2914 & 3055 & 486 & 563 \\
& 1620 & & & & & & \\
\hline \hline
\end{tabular}

T a ble 3

$U V$-Vis spectrum values ( $\mathrm{nm}$ ) of synthesized dendrimers

\begin{tabular}{lccccc}
\hline \hline \multirow{2}{*}{ Compound } & \multicolumn{5}{c}{$\lambda \max \left(10^{-4} \mathrm{M}\right.$ DMF $)$} \\
\cline { 2 - 6 } & $\sigma \rightarrow \sigma^{*}$ & $\pi \rightarrow \pi^{*}(\mathrm{bnz})$ & $\pi \rightarrow \pi^{*}(\mathrm{C}=\mathrm{N})$ & $\mathrm{n} \rightarrow \pi^{*}{ }_{(\mathrm{C}=\mathrm{N})}$ & $\mathrm{d} \rightarrow \mathrm{d}(\mathrm{Fc})$ \\
\hline $2 \mathrm{G}-\mathrm{NO}_{2}-\mathrm{Pt}(\mathrm{II})$ & 201 & 234 & 253 & 300 & 389 \\
$2 \mathrm{G}-\mathrm{NO}_{2}-\mathrm{Pt}(\mathrm{IV})$ & 207 & 231 & 257 & 296 & 392 \\
\hline \hline
\end{tabular}

\subsection{Studies for biocatalysis}

In this study, the amount of loaded enzyme per gram of dendrimers was defined as the saturation ratio (s.r.). This ratio was calculated by the following formula (for $2 \mathrm{G}$, [2G-NO $2-\mathrm{Pt}(\mathrm{II})]$ and $\left.\left[2 \mathrm{G}-\mathrm{NO}_{2}-\mathrm{Pt}(\mathrm{IV})\right]\right)$ :

$$
\mathrm{A}_{412}=\varepsilon \times \mathrm{b} \times \mathrm{C}_{20 \mu \mathrm{ll}, 0.075 \mathrm{M}}
$$

As.o.(412) $=\varepsilon \times \mathrm{b} \times \mathrm{C}_{(20 \mu \mathrm{l}, 0.075 \mathrm{M}-\text { immobilized AChE) }}$

\subsection{Influence of pH on enzyme activity}

The optimum $\mathrm{pH}$ for the activity of free and immobilized $\mathrm{AChE}$ was determined by measuring the activity of free and immobilized enzymes in buffers of different $\mathrm{pH}$ values ranging from 3 to 9 . Both the free enzyme and the immobilized dendrimers have the highest relative activity at $\mathrm{pH} 8$.

\subsection{Influence of temperature on enzyme activity}

Free and immobilized enzymes were incubated in the reaction mixtures at different tempera- tures ranging from $20{ }^{\circ} \mathrm{C}$ to $90{ }^{\circ} \mathrm{C}$ by measuring the residual activity of the enzyme after incubation for 30 minutes. The activities of the immobilized enzyme were plotted against respective temperature. The optimum temperature for immobilized AChE on $2 \mathrm{G}$, [2G-NO $\left.{ }_{2}-\mathrm{Pt}(\mathrm{II})\right]$ and $\left[2 \mathrm{G}-\mathrm{NO}_{2}-\mathrm{Pt}(\mathrm{IV})\right]$ was determined as $60{ }^{\circ} \mathrm{C}, 40^{\circ} \mathrm{C}$ and $60^{\circ} \mathrm{C}$, respectively. The free enzyme has shown an optimum temperature as $30^{\circ} \mathrm{C}$. The shift of the optimum temperature toward higher temperatures is an indication of greater thermal stability for the enzyme after the immobilization process.

\subsection{Kinetic parameters for free AChE and immobilized AChE}

The effect of the substrate concentration was examined at the optimum $\mathrm{pH}$ and at the optimum temperature that we had previously determined. For this purpose, absorbance values of substrate solutions were determined, and various graphs $(1 / S$ versus $1 / V$ ) were drawn. The $K_{\mathrm{m}}$ and $V_{\max }$ values calculated from these graphs are given in Table 4 [28].

Table 4

Kinetic parameters $\left(K_{\mathrm{m}} / V_{\mathrm{max}} ; \mathrm{mM} / \mathrm{mM} \mathrm{min}^{-1}\right)$ for free AChE and immobilized AChE

\begin{tabular}{|c|c|c|c|c|c|c|}
\hline \multirow[t]{2}{*}{ Symbol of dendrimers } & \multirow[t]{2}{*}{$\mathrm{pH}$} & \multirow[t]{2}{*}{$\mathrm{T}\left({ }^{\circ} \mathrm{C}\right)$} & \multicolumn{2}{|c|}{ "Dendrimer-AChE } & \multicolumn{2}{|c|}{ Free enzyme } \\
\hline & & & $K_{\mathrm{m}}$ & $V_{\max }$ & $K_{\mathrm{m}}$ & $V_{\max }$ \\
\hline 2G-AChE & 8 & 60 & 0.20 & 0.44 & 0.07 & 4.32 \\
\hline 2G-NO $2-\mathrm{Pt}(\mathrm{II})-\mathrm{AChE}$ & 8 & 40 & 0.30 & 0.38 & 0.99 & 2.06 \\
\hline $2 \mathrm{G}-\mathrm{NO}_{2}-\mathrm{Pt}(\mathrm{IV})-\mathrm{AChE}$ & 8 & 60 & 0.33 & 0.33 & 0.07 & 4.32 \\
\hline
\end{tabular}


Kinetic parameters were studied for free $\mathrm{AChE}$ and immobilized $\mathrm{AChE}$ at $\mathrm{pH}=8$ and at a temperature of $60{ }^{\circ} \mathrm{C}$ for $2 \mathrm{G}$-AChE, $40{ }^{\circ} \mathrm{C}$ for [2G$\left.\mathrm{NO}_{2}-\mathrm{Pt}(\mathrm{II})\right]-\mathrm{AchE}$ and $60{ }^{\circ} \mathrm{C}$ for [2G-NO $\left.2-\mathrm{Pt}(\mathrm{IV})\right]-$ AChE). The determined $K_{\mathrm{m}} / V_{\max }$ values, which show the affinity of the enzyme to substrate, for free and immobilized AChE were found to be about $0.20 / 0.44,0.30 / 0.38$ and $0.33 / 0.33 \mathrm{mM} / \mathrm{mM}$ $\min ^{-1}$, respectively. The $V_{\max }$ value of the enzyme decreased after immobilization onto the $\left[2 \mathrm{G}_{-} \mathrm{NO}_{2}-\right.$ $\mathrm{Pt}(\mathrm{II})]$ and $\left[2 \mathrm{G}-\mathrm{NO}_{2}-\mathrm{Pt}(\mathrm{IV})\right]$, but not upon the immobilization to the $2 \mathrm{G}$ due to the platinum-enzyme complex. Due to the steric effects, interaction of acetylcholine may be prevented. According to $K_{\mathrm{m}}$, the affinity of the AChE immobilized on $2 \mathrm{G}$ to the substrate is greater than the $\left[2 \mathrm{G}-\mathrm{NO}_{2}-\mathrm{Pt}(\mathrm{II})\right]$ and $\left[2 \mathrm{G}-\mathrm{NO}_{2}-\mathrm{Pt}(\mathrm{IV})\right]$.

\subsection{Storage stability and reusability}

The storage stability of enzymes is one of their most important characteristics: it is common

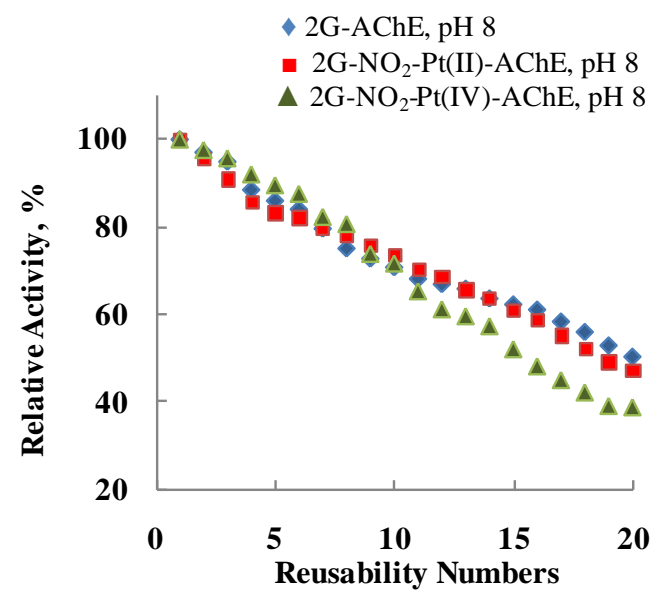

knowledge that enzymes halt their activity during storage. In this study, free and immobilized enzymes were stored in a dark bottle at $+4{ }^{\circ} \mathrm{C}$ for 8 months (Fig. 4). When the studies on storage stability were evaluated, it was observed that the relative activities were maintained at a $95 \%$ level at the end of 1 month. After 6 months, approximately $80 \%$ of the relative activity of $2 \mathrm{G}-\mathrm{AChE}$ is maintained, while the $\mathrm{Pt}(\mathrm{II})$ and $\mathrm{Pt}(\mathrm{IV})$ complexes are maintained at about a $75 \%$ level. The relative activity of $2 \mathrm{G}^{-\mathrm{NO}_{2}}$-Pt (IV)-AChE between the immobilized dendrimers was found to be the lowest, at a $65.9 \%$ level after 8 months.

2G-AChE, [2G-NO 2 -Pt(II)]-AChE and [2G$\mathrm{NO}_{2}$-Pt(IV)]-AChE were used repeatedly 10 times, and the residual activity was about $70.69 \%, 73.55 \%$ and $71.67 \%$ of their initial levels, respectively. Furthermore, $2 \mathrm{G}-\mathrm{AChE}$ was used repeatedly 20 times (50.18\% residual activity). Therefore, performance on the recycling stability of [2G-NO $-\mathrm{Nt}(\mathrm{II})]-\mathrm{AChE}$ was better than $\left[2 \mathrm{G}-\mathrm{NO}_{2}-\mathrm{Pt}(\mathrm{IV})\right]-\mathrm{AChE}$.

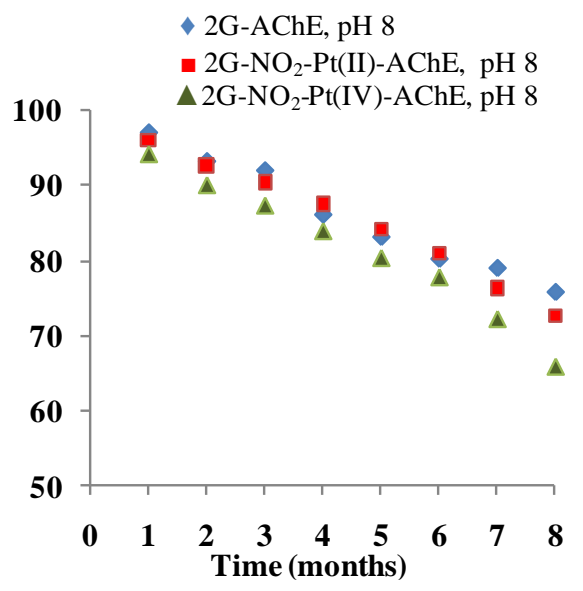

Fig. 4. Storage stability and reusability for immobilized enzymes

\subsection{Evaluation of the results of the inhibition of immobilized dendrimers with diclofop-methyl}

Changes in absorbance intensity were recorded as a result of the addition of the pesticide solution, ranging between 10 and $50 \mu 1$ in the environment of immobilized dendrimers (Fig. 5). The amount of pesticides required to halve the enzyme activity is shown in Figure 6. When the immobilized dendrimers were compared, it was seen that less herbicide was needed to reduce the enzyme activity of $\mathrm{Pt}(\mathrm{II})$ ion containing dendrimers to $50 \%$, whereas, it was found that this value was significantly higher for the $2 \mathrm{G}$. Calibration graphs were investigated, and it was seen that the required amounts of pesticide to reduce the enzyme activity were found to be $90.69 \mu \mathrm{l}, 40.01 \mu \mathrm{l}$ and $45.60 \mu \mathrm{l}$ for 2G-AChE, [2G-NO 2 -Pt(II)]-AChE and [2G$\mathrm{NO}_{2}$-Pt(IV)]-AChE, respectively (Fig. 6). Therefore, it was concluded that the use of the $2 \mathrm{G}-\mathrm{AChE}$ ligand in the detection of diclofop-methyl would not be economical.

The inhibition interaction of the enzyme immobilized to the dendrimers containing the $\mathrm{Pt}(\mathrm{II})$ ion with herbicide was higher than the inhibition interaction with immobilized dendrimers containing the $\mathrm{Pt}(\mathrm{IV})$ ion. The reason for this behaviour is that $\mathrm{Pt}(\mathrm{II})$ dendrimers have a planar structure and are effective in maintaining the threedimensional structure of the enzyme. 

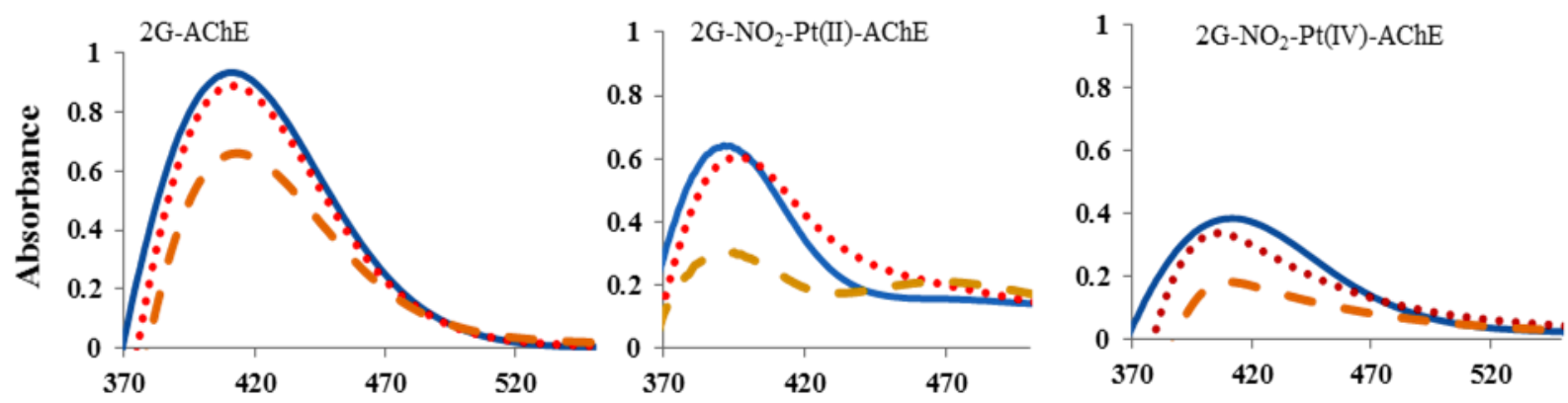

Wavelength (nm)

Fig. 5. Spectral change of diclofop-methyl herbicide interacting with immobilized dendrimer is given (10 $\mu 1$ diclofop-methyl+immobilized dendrimers (red line); $50 \mu 1$ diclofop-methyl+immobilized dendrimers (brown line)).
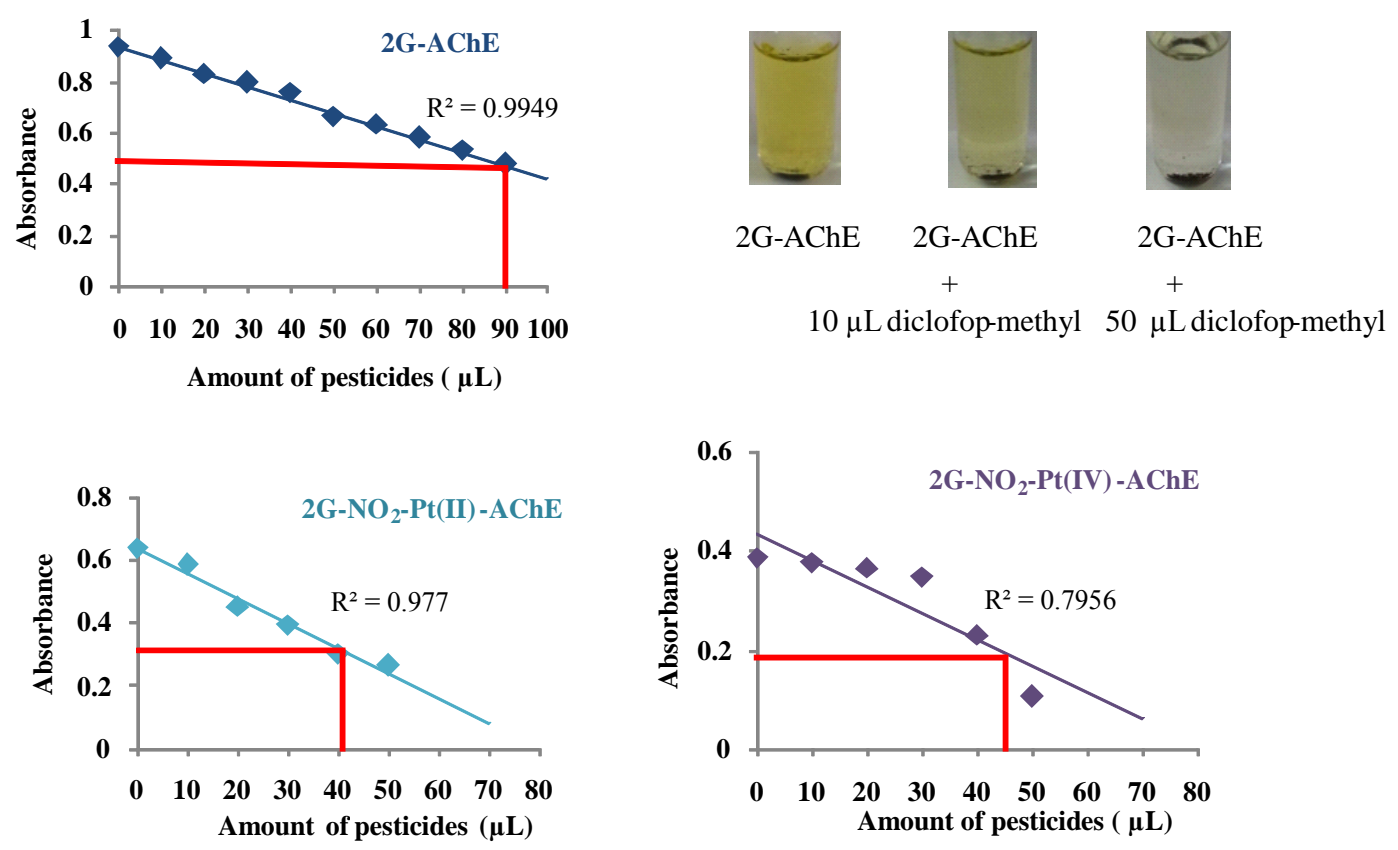

Fig. 6. The calibration graphs of the pesticide amounts that are necessary to reduce the enzyme activity by $50 \%$

\section{CONCLUSIONS}

Acetylcholinesterase is a classical biomarker used to monitor the contamination and poisoning of organophosphate (OP) and carbamate pesticides. The use of the AChE enzyme for the determination of herbicides was much less studied then for the organophosphate and carbamate pesticides [29, 30]. For this purpose, ferrocene containing dendrimers were prepared for the determination of herbicides, and the immobilization of the AChE enzyme was performed. The kinetic parameters were calculated at the end of the immobilization, and it was observed that the $K_{\mathrm{m}}$ value of the $2 \mathrm{G}$ $\mathrm{NO}_{2}$-Pt (II) immobilized dendrimer was significantly lower than that of the free enzyme. The re- sult showed that the immobilized enzyme was more related to the substrate than the free enzyme.

When the studies on the herbicide detection of the immobilized enzyme were examined, the inhibition interaction of the enzyme immobilized to the dendrimers containing the $\mathrm{Pt}(\mathrm{II})$ ion with the herbicide was higher than the inhibition interaction with immobilized dendrimers containing the Pt(IV) ion. The $\mathrm{Pt}(\mathrm{II})$ ion containing immobilized dendrimers should be used to determine herbicides in low concentrations. Taken together, these results suggest that enzymes with a high cost of purification can be immobilized on functional dendrimers. Hence, they can contribute to the preparation of affordable and reliable sensors with high levels of sensitivity. 
Acknowledgements. This work was supported by the Gazi University Research Fund (Project number: 05/2016-10).

\section{REFERENCES}

[1] J. M. Frechet, C. J. Hawker, K. L. Wooley, The convergent route to globular dendritic macromolecules - a versatile approach to precisely functionalized 3-dimensional polymers and novel block-copolymers, J. Macromol. Sci. Part A Pure Appl. Chem. 31, 1627-1645 (1994). DOI: https://doi.org/10.1080/10601329408545873

[2] T. Sakthivel, A. T. Florence, Adsorption of amphipathic dendrons on polystyrene nanoparticles, Int. J. Pharm. 254, 23-26 (2003).

DOI: https://doi.org/10.1016/S0378-5173(02)00671-3

[3] J. M. J. Frechet, Functional polymers and dendrimers: Reactivity, molecular architecture, and interfacial energy, Science, 263, 1710-1715 (1994). DOI: https://doi.org/10.1126/science. 8134834

[4] U. Boas, J. B. Christensen, P. M. H. Heegaard, Dendrimers: Design, synthesis and chemical properties, J. Mater. Chem. 16, 3785-3798 (2006). DOI: https://doi.org/10.1039/B611813P

[5] F. N. Crespilho, M. E. Ghica, M. Florescu, F. C. Nart, O. N. Oliveira Jr, C. M. A. Brett, Strategy for enzyme 1mmobilization on layer-by-layer dendrimer-gold nanoparticle electrocatalytic membrane incorporating redox mediator, Electrochem. Commun. 8, 1665-1670 (2006). DOI: https://doi.org/10.1016/j.elecom.2006.07.032

[6] L. Svobodova, M. Snejdarkova, T. Hianik, Properties of glucose biosensors based on dendrimer layers. Effect of enzyme 1mmobilization, Anal. Bioanal. Chem. 373, 735-741 (2002).

DOI: https://doi.org/10.1007/s00216-002-1419-3

[7] G. R. Newkome, E. He, C. N. Moorefield, Suprasupermolecules with novel properties: Metallodendrimers, Chem. Rev. 99, 1689-1746 (1999), DOI: https://doi.org/10.1021/cr9800659

[8] C. M. Casado, I. Cuadrado, M. Morán, B. Alonso, B. García, B. González, J. Losada, Redoxactive ferrocenyl dendrimers and polymers in solution and immobilised on electrode surfaces, Coord. Chem. Rev. 185, 53-79 (1999). DOI: https://doi.org/10.1016/S0010-8545(98)00252-5

[9] E. Peris, From long-chain conjugated oligomers to dendrimers: Synthesis and physical properties of phenylethenyl-ferrocenyl containing one- and two-dimensional complexes, Coord. Chem. Rev. 248, 279-297 (2004). DOI: https://doi.org/10.1016/j.ccr.2004.01.006

[10] J. H. Lee, Y. D. Han, S. Y. Song, T. D. Kim, H. C. Yoon, Biosensor for organophosphorus pesticides based on the acetylcholine esterase inhibition mediated by choline oxidase bioelectrocatalysis, Bio. Chip. J. 4, $223-$ 229 (2010).

DOI: https://doi.org/10.1007/s13206-010-4310-x

[11] P. Nicolopoulou-Stamati, S. Maipas, C. Kotampasi, P. Stamatis, L. Hens, Chemical pesticides and human health: the urgent need for a new concept in agriculture, Front. Public Health, 4, 1-8 (2016).

DOI: https://doi.org/10.3389/fpubh.2016.00148
[12] U. Blaznik, A. Yngve, I. Erzen, C. Hlastan Ribic, Consumption of fruits and vegetables and probabilistic assessment of the cumulative acute exposure to organophosphorus and carbamate pesticides of schoolchildren in Slovenia, Public Health Nutr. 19, 557-563, (2016).

DOI: https://doi.org/10.1017/S1368980015001494

[13] Md. W. Aktar, D. Sengupta, A. Chowdhury, Impact of pesticides use in agriculture: their benefits and hazards, Interdiscip. Toxicol. 2(1), 1-12 (2009). DOI: https://doi.org/10.2478/v10102-009-0001-7

[14] E. Hasanoğlu Özkan, N. Kurnaz Yetim, H. Tümtürk, N. Sar1, Immobilization of acetylcholinesterase on $\mathrm{Pt}(\mathrm{II})$ and $\mathrm{Pt}(\mathrm{IV})$ attached nanoparticles for the determination of pesticides, Dalton Trans. 44, 16865-16872 (2015). DOI: https://doi.org/10.1039/C5DT03004H

[15] M. E. I. Badawy, A. F. El-Aswad, Bioactive paper sensor based on the acetylcholinesterase for the rapid detection of organophosphate and carbamate pesticides, Int. J. Anal. Chem. 2014, 1-8 (2014). DOI: https://doi.org/10.1155/2014/536823

[16] P. Skládal, Detection of organophosphate and carbamate pesticides using disposable biosensors based on chemically modified electrodes and 1mmobilized cholinesterase, Anal. Chim. Acta, 269, 281-287 (1992). DOI: https://doi.org/10.1016/0003-2670(92)85414-2

[17] W. Liu, Z. Chen, H. Xu, Y Shi, Y. Chen, Determination of diclofop-methyl and diclofop residues in soil and crops by gas chromatography, J. Chromatogr. 541, 509515 (1991).

DOI: https://doi.org/10.1016/S0021-9673(01)88681-7

[18] G. Özhan, S. Özden, B. Alpertunga, Determination of commonly used herbicides in surface water using solidphase extraction and dual-column HPLC-DAD, J. Environ. Sci. Health., Part B, 40, 827-840 (2005). DOI: https://doi.org/10.1080/03601230500227517

[19] S. Baali, S. Zougar, R. Kherrat, Z. Djeghaba, F. Benamia, N. Jaffrezic-Renault, Electrochemical characterization of enzymatic impedimetric biosensor destined to detect organochlorine pesticide: The diclofop-methyl, Sens. Transducers, 149, 135-142 (2013).

[20] N. Kurnaz Yetim, N. Sar1, Novel dendrimers containing redox mediator: Enzyme immobilization and applications, J. Mol. Struct. 1191, 158-164 (2019). DOI: https://doi.org/10.1016/j.molstruc.2019.04.090

[21] N. Kurnaz Yetim, Synthesis of new Pt(II), Pt(IV) dendrimers containing ferrocene and immobilization usage, Ph.D. Thesis, Gazi University Graduate School of Natural and Applied Sciences, Ankara, Turkey, 2016.

[22] G. L. Ellman, K. D. Courtney, V. Andres R. M. A. Featherstone, New and rapid colorimetric determination of acetylcholinesterase activity, Biochem. Pharmacol. 7, 88-95 (1961). DOI: https://doi.org/10.1016/0006-2952(61)90145-9

[23] W. J. Geary, The use of conductivity measurements in organic solvents for the characterisation of coordination compounds, Coord. Chem. Rev. 7, 81-122 (1970). DOI: https://doi.org/10.1016/S0010-8545(00)80009-0

[24] M. Şenel, C. Nergiz, E. Çevik, Novel reagentless glucose biosensor based on ferrocene cored asymmetric 
PAMAM dendrimers, Sensor. Actuat. B-Chem. 176, 299-306 (2013).

DOI: https://doi.org/10.1016/j.snb.2012.10.072

[25] Ş. Uysal, İ. Uçan, The synthesis and characterization of melamine based Schiff bases and its trinuclear [salen/salophenFe(III)] and [salen/salophenCr(III)] capped complexes, J. Inclusion Phenom. Macrocyclic Chem. 65, 299-304 (2009).

DOI: https://doi.org/10.1007/s10847-009-9581-2

[26] R. Trivedi, S. B. Deepthi, L. Giribabu, B. Sridhar, P. Sujitha, C. G. Kumar, K. V. S. Ramakrishna, Synthesis, crystal structure, electronic spectroscopy, electrochemistry and biological studies of carbohydrate containing ferrocene amides, Appl. Organomet. Chem. 26, 369-376 (2012).

DOI: https://doi.org/10.1002/aoc.2874

[27] N. Kurnaz Yetim, E. Hasanoğlu Özkan, B. Danış, H. Tümtürk, N. Sar1, Research on the repeated use of novel ferrocene-tagged nanomaterial for determination of glucose, Int. J. Polym. Mater. 64, 888-893 (2015). DOI: https://doi.org/10.1080/00914037.2015.1030659

[28] E. Hasanoğlu Özkan, N. Kurnaz Yetim, M. Gümüş, N. Sarı, A. Dişli, Efficient determination and pesticide control by means of immobilization of acetylcholinesterase, Maced. J. Chem. Chem. Eng. 36 (1), 119-128 (2017).

DOI: https://doi.org/10.20450/mjcce.2017.1178

[29] X. Wang, J. Li, H. Xing, S. Xu, Review of toxicology of atrazine and chlorpyrifos on fish, J. Northeast Agric. Univ. 18 (4), 88-92 (2011).

DOI: https://doi.org/10.1016/S1006-8104(12)60031-2

[30] K. E. Larsen, A. L. Lifschitz, C. E. Lanusse, G. L. Virkel, The herbicide glyphosate is a weak nnhibitor of acetylcholinesterase in rats, Environ. Toxicol. Pharmacol. 45, 41-44 (2016).

DOI: https://doi.org/10.1016/j.etap.2016.05.012 
